\title{
Thioalbus denitrificans gen. nov., sp. nov., a chemolithoautotrophic sulfur-oxidizing gammaproteobacterium, isolated from marine sediment
}

\author{
Soo-Je Park, Vinh Hoa Pham, ${ }^{\dagger}$ Man-Young Jung, So-Jeong Kim, \\ Jong-Geol Kim, Dong-Hyun Roh and Sung-Keun Rhee
}

Correspondence

Sung-Keun Rhee

rhees@chungbuk.ac.kr

\author{
Department of Microbiology, Chungbuk National University, 12 Gaeshin-dong, Cheongju 361-763, \\ Republic of Korea
}

\begin{abstract}
A mesophilic, facultatively anaerobic, autotrophic bacterium, designated strain $\mathrm{Su} 4^{\top}$, was isolated from marine sediment. The isolate was able to utilize reduced sulfur compounds including thiosulfate, tetrathionate, sulfur and sulfide but not sulfite as the energy source. Growth occurred under aerobic and denitrifying chemolithoautotrophic conditions in the presence of thiosulfate as an electron donor and bicarbonate as a carbon source. The $G+C$ content of the genomic DNA was 64.5 mol\%. Comparative 16S rRNA gene sequence studies showed that strain Su $4^{\top}$ was clearly affiliated with the class Gammaproteobacteria. The isolate was Gram-negative-staining and rod-shaped, lacked flagella and grew in artificial seawater medium at $10-40{ }^{\circ} \mathrm{C}$ (optimum 28-32 ${ }^{\circ} \mathrm{C}$ ) and in 1-5\% (w/v) NaCl (optimum 3\% NaCl). Strain $\mathrm{Su}^{\top}{ }^{\top}$ possessed $\mathrm{C}_{16: 0 \text {, }}$ $\mathrm{C}_{16: 1} \omega 7 \mathrm{c} /$ iso- $\mathrm{C}_{15: 0} 2-\mathrm{OH}$ and $\mathrm{C}_{18: 1} \omega 7 \mathrm{c} / \omega 9 \mathrm{t} / \omega 12 \mathrm{t}$ as the major fatty acids. On the basis of phenotypic and phylogenetic analysis, the isolate represents a novel species of a novel genus, for which the name Thioalbus denitrificans is proposed. The type strain is Su $4^{\top}\left(=\mathrm{KCTC}^{2} 699^{\top}\right.$ $\left.=J C M 15568^{\top}\right)$.
\end{abstract}

Sulfur is a constituent of living organisms and is biogeochemically cycled on the earth. Reduced inorganic sulfur compounds generated by sulfur-reducing bacteria in anoxic environments are oxidized to sulfate by some bacteria and archaea under aerobic conditions (Friedrich et al., 2001). Oxidation of reduced inorganic sulfur compounds mediated by micro-organisms is one of the major reactions in marine sediments (Sorokin, 2003). Sulfur oxidizing bacteria have been isolated from various oxic and anoxic environments (Ito et al., 2004; Kelly et al., 2000; Kuenen \& Robertson, 1992; McHatton et al., 1996; Otte et al., 1999; Sorokin \& Mityushina, 1998; Sorokin et al., 2000; Sorokin et al., 2007a; Sorokin et al., 2008; Sorokin et al., 2002a; Sorokin et al., 2002b; Sorokin et al., 2006b; Sorokin et al., 2001b) and even under extreme conditions such as those associated with deep-sea hydrothermal vents (Nakagawa \& Takai, 2008), solfataras (Kletzin et al., 2004), hypersaline environments (Rijkenberg et al., 2001; Sorokin \& Mityushina, 1998; Sorokin

tPresent address: Department of Biological Sciences, National University of Singapore, 14 Science Drive 4, Singapore.

Abbreviations: NJ, neighbour-joining; ML, maximum-likelihood.

The GenBank/EMBL/DDBJ accession number for $16 \mathrm{~S}$ rRNA gene sequence of strain Su4 $4^{\top}$ is EU837269.

A supplementary figure is available with the online version of this paper. et al., 1996; Sorokin et al., 2000; Sorokin et al., 2001a; Sorokin et al., 2002a; Sorokin et al., 2006a; Sorokin et al., 2002c; Sorokin et al., 2001b) and volcanic environments (King, 2007). Sulfur is oxidized by chemotrophic and phototrophic bacteria which are phylogenetically and physiologically diverse (Friedrich et al., 2001; Friedrich et al., 2005). The cellular processes of inorganic sulfur metabolism in prokaryotes are well established (Dahl \& Friedrich, 2007) although the significance of these processes and their contribution to bacterial habitats are poorly described.

Here, we describe the properties of a novel, slightly halophilic, obligately chemolithoautotrophic and facultatively anaerobic, sulfur-oxidizing bacterium, designated strain $\mathrm{Su} 4^{\mathrm{T}}$, isolated from marine sediment. Strain $\mathrm{Su} 4^{\mathrm{T}}$ was isolated from an anaerobic enrichment culture oxidizing sulfur compounds. The inoculum was collected from marine sediment of the East Sea, South Korea. A $3 \mathrm{~g}$ sediment sample was collected in a sterile conical tube and serially diluted in filter-sterilized $(0.22 \mu \mathrm{m}$ pore size, Millipore) natural sea water containing $3 \mathrm{mM}$ thiosulfate as a sole electron donor, $6 \mathrm{mM}$ nitrate as an electron acceptor and the following supplements (per 1 filter-sterilized natural sea water): trace element mixture $(1 \times)$ (Widdel \& Bak, 1992), $0.001 \mathrm{~g}$ resazurin, $3 \mathrm{mM}$ bicarbonate, $0.1 \mathrm{mM}$ phosphate and vitamin solution $(1 \times)$ (Wolin et al., 1963). 
Medium without supplements was dispensed into anaerobic pressure tubes or serum bottles and bubbled with oxygen-free $\mathrm{N}_{2}$ gas to remove dissolved oxygen. Before autoclaving, the tubes or bottles were closed with butylrubber stoppers and capped with aluminium seals. All preparations of enrichment cultures, serial dilutions and inoculations were performed under strictly anaerobic conditions in an anaerobic glove box (Coy Laboratory Products) containing an atmosphere of mixed gases $\left(\mathrm{N}_{2} /\right.$ $\left.\mathrm{CO}_{2} / \mathrm{H}_{2}, 90: 5: 5, \mathrm{v} / \mathrm{v} / \mathrm{v}\right)$. The supplement solutions were filter-sterilized and added to the autoclaved medium. If necessary, the $\mathrm{pH}$ was adjusted to $7.5-8.0$ by adding $1 \mathrm{M}$ $\mathrm{NaOH}$ or $\mathrm{HCl}$. The mixture was anaerobically incubated at $25{ }^{\circ} \mathrm{C}$ in tubes or bottles and subcultured every 2-3 weeks with $10 \%(\mathrm{v} / \mathrm{v})$ transfer. After five subculturings in the natural seawater medium, the culture was spread onto the solid artificial sea water medium (ASWM), containing $3 \mathrm{mM}$ thiosulfate and $1.5 \%(\mathrm{w} / \mathrm{v})$ agarose, in $20 \mathrm{~g} \mathrm{l}^{-1}$ sea salts (Sigma), and incubated at $25{ }^{\circ} \mathrm{C}$ for 2 weeks under anaerobic and aerobic conditions. The ASWM broth or agar contained the following supplements $\left(1^{-1}\right)$ : trace element mixture $(1 \times)$ (Widdel \& Bak, 1992), $0.001 \mathrm{~g}$ resazurin, $3 \mathrm{mM}$ bicarbonate, $0.1 \mathrm{mM}$ phosphate and vitamin solution $(1 \times)$ (Wolin et al., 1963). Cells of the isolated strain were able to grow under aerobic as well as anaerobic conditions but the growth rate was higher under aerobic conditions. The strain was preserved at $-80{ }^{\circ} \mathrm{C}$ as suspensions in ASWM containing $20 \%(\mathrm{w} / \mathrm{v})$ glycerol.

For phylogenetic analysis of strain $\mathrm{Su} 4^{\mathrm{T}}$, genomic DNA was extracted using a commercial genomic DNA extraction kit (Solgent). The 16S rRNA gene was amplified from the chromosomal DNA using the universal bacterial primers 27F (5'-AGAGTTTGATCMTGGCTCAG-3'; E. coli position
8-27) and 1492R (5'-TACGGYTACCTTGTTACGACTT-3'; E. coli position 1492-1510) (Park et al., 2006; Weisburg et al., 1991). The purified PCR products were sequenced by Solgent using primers 27F, 338F, 786R and 1492R (Weisburg et al., 1991). The nearly complete $16 \mathrm{~S}$ rRNA gene sequence of strain $\mathrm{Su} 4^{\mathrm{T}}$ was obtained $(1417 \mathrm{bp}$ ), and then compiled by using SeqMan software (DNASTAR). The $16 \mathrm{~S}$ rRNA gene sequences of related taxa were obtained from the GenBank database. Sequence alignments were performed by using the CLUSTAL_X program (Thompson et al., 1997). Gaps were edited in the BioEdit program (Hall, 1999). Nucleotide similarity values of the $16 S$ rRNA gene sequences were calculated by using the EzTaxon program (http://www.eztaxon.org) (Chun et al., 2007). Evolutionary distances were calculated by using the Kimura twoparameter model (Kimura, 1983). Phylogenetic trees were reconstructed based on the neighbour-joining (NJ; Saitou \& Nei, 1987) and maximum-likelihood (ML; Felsenstein, 1981) methods by using the MEGA4 (Tamura et al., 2007) and PHYLIP programs (Felsenstein, 1993), respectively. Bootstrap analysis was performed with 1000 resampled datasets by using the built-in programs of the software. In the phylogenetic analysis, strain $\mathrm{Su} 4^{\mathrm{T}}$ was closely related to members of the unclassified family of the class Gammaproteobacteria. The novel strain was most closely related to members of the genera Thiohalomonas (91.4$92.8 \% 16 \mathrm{~S}$ rRNA gene sequence similarity), Thioalkalivibrio (92.2-92.4\%), Thiohalospira (89.8-91.8\%), Thiorhodospira (91.2\%), Ectothiorhodospira (92.0\%), Thioalkalispira (90.6\%) and Thiohalophilus (90.9\%) (Fig. 1). In the phylogenetic tree based on 16S rRNA gene sequences, strain Su $4^{\mathrm{T}}$ formed a monophyletic clade in the unclassified Grammaproteobacteria and was most closely related to Thiohalomonas denitrificans HLD $2^{\mathrm{T}}(92.8 \%)$ (Fig. 1) (Sorokin et al., 2007a). The

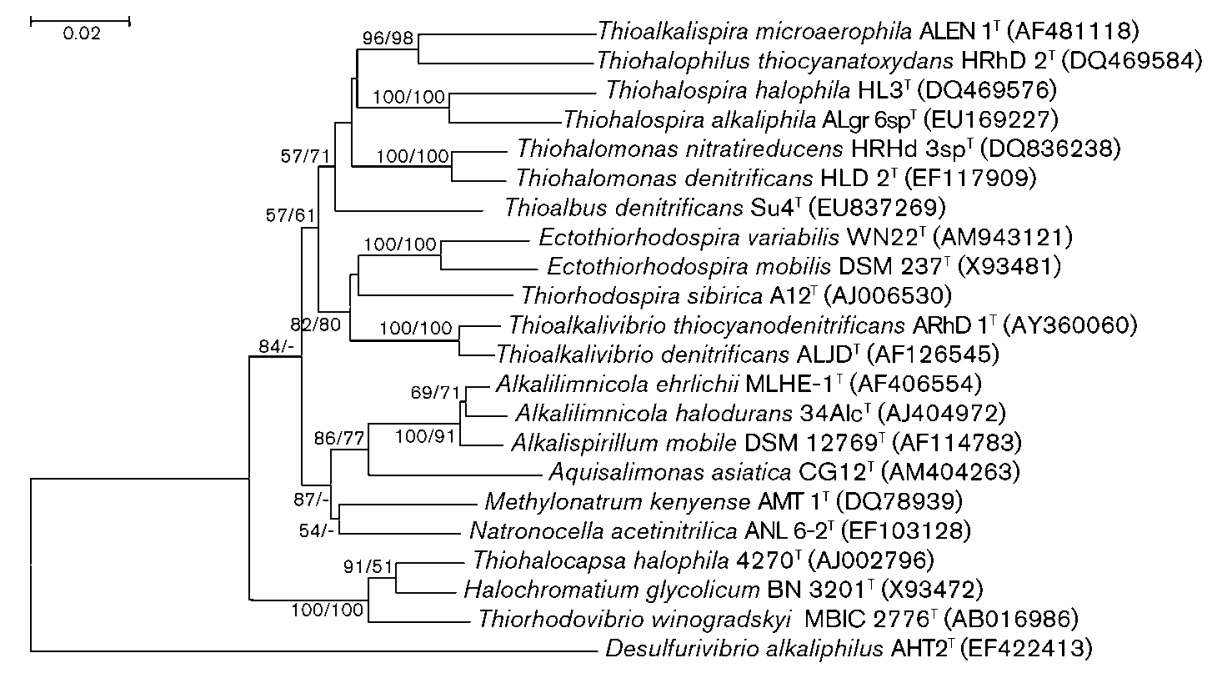

Fig. 1. Phylogenetic tree based on $16 \mathrm{~S}$ rRNA gene sequences showing the position of strain Su $4^{\top}$ and related taxa. GenBank accession numbers are given in parentheses. Bar, 0.02 substitutions per nucleotide position. Bootstrap values $\geqslant 50 \%$ (based on 1000 replicates) from neighbour-joining (NJ) and maximum-likelihood (ML) methods, respectively, are indicated at branch points; values $<50 \%$ are indicated by a dash. 
phylogenetic topology of the NJ and ML trees showed that the clade containing strain $\mathrm{Su} 4^{\mathrm{T}}$ comprised typical sulfuroxidizing bacteria. $16 \mathrm{~S}$ rRNA gene sequence similarity values below the recommended threshold value of $97 \%$ (Wayne et al., 1987) between strain $\mathrm{Su} 4^{\mathrm{T}}$ and related taxa established strain $\mathrm{Su} 4^{\mathrm{T}}$ as a distinct genospecies.

Cell morphology and size were determined by phasecontrast microscopy (Eclipse 80i; Nikon). For the preparation of cells of strain $\mathrm{Su} 4^{\mathrm{T}}$ for scanning electron microscopy $(\mathrm{SEM})$, cells were harvested and immersed in $4 \%(\mathrm{v} / \mathrm{v})$ glutaraldehyde and $0.1 \mathrm{M}$ sodium phosphate buffer $(\mathrm{pH} 7.2)$ for $24 \mathrm{~h}$ at $4{ }^{\circ} \mathrm{C}$, and dehydrated through a graded ethanol series $(70-100 \%)$. The specimens were examined with a Zeiss DSM 940 scanning electron microscope (Carl Zeiss). To enable transmission electron microscopic analysis of strain Su $4^{\mathrm{T}}$, cells were fixed in a $2.5 \%$ paraformaldehyde/ $1.5 \%$ glutaraldehyde mixture buffered with $0.1 \mathrm{M}$ sodium phosphate buffer ( $\mathrm{pH} 7.2$ ) for $2 \mathrm{~h}$ at $4{ }^{\circ} \mathrm{C}$, post-fixed in $1 \%$ osmium tetroxide in the same buffer for $1 \mathrm{~h}$, dehydrated in a graded ethanol series $(-100 \%)$, transferred to propylene oxide and embedded in Epon-812 medium (TAAB). Ultrathin sections generated with an UltraCut E (Leica) ultramicrotome were stained with uranyl acetate and lead citrate and examined with a CM 20 electron microscope 405 (Philips). Gram staining was performed with Gram stain kits (BD) according to the instructions of the manufacturer. Catalase activity was determined by bubble production in $3 \%(\mathrm{v} / \mathrm{v})$ hydrogen peroxide solution and oxidase activity was determined using $1 \%(\mathrm{w} / \mathrm{v})$ tetramethyl $p$-phenylenediamine (Merck). Cells of strain Su $4^{\mathrm{T}}$ were Gram-negativestaining, oxidase- and catalase-positive, non-motile and rod-shaped and varied in size $(0.5-0.8 \times 1.2-1.5 \mu \mathrm{m})$ (Fig. 2). Elemental sulfur was accumulated when strain $\mathrm{Su} 4^{\mathrm{T}}$ was grown with thiosulfate as electron donor under anaerobic conditions (Supplementary Fig. S1, available in IJSEM Online). The methyl red/Voges-Proskauer test and tests for indole production and $\mathrm{H}_{2} \mathrm{~S}$ production were negative. Since anaerobic growth was observed under denitrifying conditions (nitrate as sole electron acceptor and thiosulfate as sole electron donor), strain $\mathrm{Su} 4^{\mathrm{T}}$ was characterized as a facultative anaerobe. Colonies of strain $\mathrm{Su} 4^{\mathrm{T}}$ were white, $0.7-1.5 \mathrm{~mm}$ in diameter and had entire margins when grown on ASWM agar plates under aerobic conditions for 10 days.

Heterotrophic growth was investigated in ASWM containing potential organic carbon sources; $0.01 \%(\mathrm{w} / \mathrm{v})$ each of yeast extract, tryptone, peptone and Casamino acids; $1 \mathrm{mM}$ each of succinate, glucose, glycerol, ethanol, methanol, pyruvate, malate, citrate, propionate and formate; and $0.1 \mathrm{mM}$ each of proline, alanine, aspartic acid and serine were used. Heterotrophic growth was not observed in this study with any of the carbon compounds used. Vitamins also were not required. These results strongly supported the notion that strain $\mathrm{Su} 4^{\mathrm{T}}$ could grow autotrophically.

Sulfur oxidation was evaluated with $1 \mathrm{mM}$ thiosulfate, $1 \mathrm{mM}$ tetrathionate, $1 \mathrm{mM}$ sulfite, $1 \mathrm{mM}$ sulfide and $1 \%$
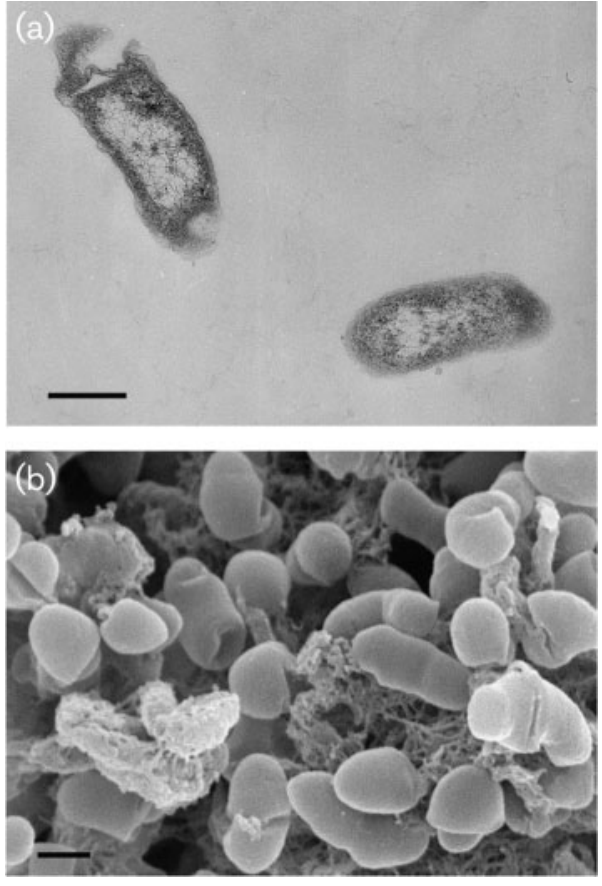

Fig. 2. Electron micrographs of cells of strain Su $4^{\top}$. Transverse thin sections of single cells (a), scanning electron micrographs of cells (b). Bar, $500 \mathrm{~nm}$.

(w/v) elemental sulfur under denitrifying conditions. Thiosulfate concentration was determined colorimetrically (Choi et al., 2009; Voroteliak et al., 1993). For the determination of thiosulfate concentration in culture supernatant, the cells of strain $\mathrm{Su} 4^{\mathrm{T}}$ were pelleted by centrifugation at 13000 r.p.m. for $7 \mathrm{~min}$. The supernatant $(100 \mu \mathrm{l})$ was removed and treated with a reagent containing $0.25 \mathrm{M} \mathrm{KCN}(20 \mu \mathrm{l}), 0.2 \mathrm{M} \mathrm{CuSO}_{4}(20 \mu \mathrm{l})$ and $0.2 \mathrm{M}$ ferric nitrate $(50 \mu \mathrm{l})$ in a glass tube. The tube was vortexed, and $\mathrm{OD}_{460}$ was measured with a Nanodrop spectrophotometer ND-1000 (Nanodrop technologies). The sulfide concentration was estimated by using the improved method of Cline (1969): $0.5 \mathrm{ml}$ samples were added to a mixture of $0.25 \mathrm{ml} 0.05 \mathrm{M}$ zinc acetate and $0.025 \mathrm{ml}$ of diamine reagent (prepared from $4.0 \mathrm{~g}$ anhydrous ferric chloride and $1.6 \mathrm{~g} \mathrm{~N}, N$-dimethyl-p-phenylene diamine sulfate with $100 \mathrm{ml} 6 \mathrm{M} \mathrm{HCl}$ ), with vortex-mixing between additions; $1 \mathrm{ml}$ of distilled water was then added after $20 \mathrm{~min}$ and $A_{670}$ was measured after $15 \mathrm{~min}$. Sulfate levels were determined turbidimetrically (Kolmert et al., 2000). Other sulfur-compound assimilation was observed indirectly via the reduction nitrate. Nitrate respiration was determined by measuring the concentration of nitrate remaining in the enrichment culture and the level of nitrite accumulated during denitrification (Strickland \& Parsons, 1968). The result showed that strain $\mathrm{Su} 4^{\mathrm{T}}$ was able to utilize thiosulfate, tetrathionate, sulfide and elementary sulfur but not sulfite. The product of thiosulfate oxidation (4 mM thiosulfate) was sulfate under aerobic (oxygen as 
electron acceptor) and denitrifying [nitrate $(8-10 \mathrm{mM})$ as electron acceptor] conditions. After thiosulfate oxidation, the amount of sulfate produced under aerobic conditions was two times greater (Fig. 3). Growth of strain $\mathrm{Su} 4{ }^{\mathrm{T}}$ was arrested by nitrite accumulation (about 3-4 mM) and nitrate reduction similar to members of the genera Thiohalomonas (Sorokin et al., 2007a) and Thiohalophilus (Sorokin et al., 2007b).

Growth at different temperatures was assessed after 14 days incubation on ASWM with $4 \mathrm{mM}$ thiosulfate. Strain $\mathrm{Su} 4^{\mathrm{T}}$ was able to grow at $4-37{ }^{\circ} \mathrm{C}$ but not at $0{ }^{\circ} \mathrm{C}$ or $>40{ }^{\circ} \mathrm{C}$ (optimum $28-32{ }^{\circ} \mathrm{C}$ ). Tolerance of salt was measured on ASWM broth containing 0-20\% (w/v) $\mathrm{NaCl}$ and $4 \mathrm{mM}$ thiosulfate. Cultures were incubated at $28{ }^{\circ} \mathrm{C}$ for 2 weeks. Cells of strain $\mathrm{Su} 4^{\mathrm{T}}$ required sodium ions for growth and grew in $1-5 \%(\mathrm{w} / \mathrm{v}) \mathrm{NaCl}$ (optimum $3 \% \mathrm{NaCl})$. Growth at pH 5-9 (intervals of $0.5 \mathrm{pH}$ units) was determined in ASWM at $28{ }^{\circ} \mathrm{C}$ for 14 days. The $\mathrm{pH}$ was adjusted with $1 \mathrm{M}$ $\mathrm{HCl}$ or $1 \mathrm{M} \mathrm{NaOH}$. Strain $\mathrm{Su} 4^{\mathrm{T}}$ grew at $\mathrm{pH} 5.5-8.5$ but not at $\mathrm{pH}$ values $<5$ or $>9$ (optimum $\mathrm{pH} 7.0-7.5$ ). The physiological characteristics of strain $\mathrm{Su} 4^{\mathrm{T}}$ are summarized in the species description and selective characteristics were compared with those of closely related genera (Table 1).

Cellular fatty acids of strain $\mathrm{Su} 4^{\mathrm{T}}$ were analysed using cells grown for 14 days on ASWM containing $4 \mathrm{mM}$ thiosulfate. Cellular fatty acids were saponified, methylated and extracted according to the protocol of the Sherlock Microbial Identification System (MIDI, 1999). Fatty acids were analysed by GC (Hewlett Packard 6890) and identified by the Microbial Identification software package. The major cellular fatty acids of strain Su4 $4^{\mathrm{T}}$ comprised $\mathrm{C}_{16: 0}(32.98 \%)$, $\mathrm{C}_{16: 1} \omega 7 c /$ iso- $\mathrm{C}_{15: 0} 2-\mathrm{OH}(32.47 \%)$ and $\mathrm{C}_{18: 1} \omega 7 c / \omega 9 t / \omega 12 t$ $(14.19 \%)$. Other fatty acids detected are shown in Table 2. Strain $\mathrm{Su} 4^{\mathrm{T}}$ could be differentiated from members of the genera Thiohalomonas and Ectothiorhodospira by differences

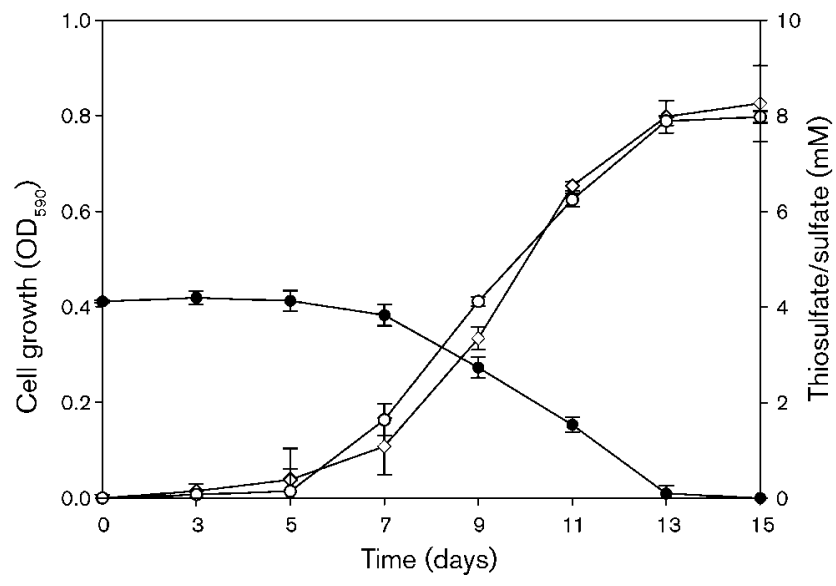

Fig. 3. Growth $(\diamond)$, thiosulfate oxidation $(\bullet)$ and sulfate production $(\bigcirc)$ in chemolithoautotrophic cultures of strain Su $4^{\top}$. Cells were cultivated under aerobic conditions. Error bar represents SD of results from triplicate experiments. in their fatty acid compositions, particularly the presence or absence of $\mathrm{C}_{16: 1} \omega 7 c, \mathrm{C}_{18: 1} \omega 7 c$ and $\mathrm{C}_{19: 0} \Delta 8,9$, as shown in Table 2. Chromosomal DNA extracted for 16S rRNA gene amplification was used for determination of $\mathrm{G}+\mathrm{C}$ content. RNA in the DNA solution was removed by incubation with a mixture of RNase A and T1 (each, 20 units $\mathrm{ml}^{-1}$ ) at $30{ }^{\circ} \mathrm{C}$ for 1 hour. The $\mathrm{G}+\mathrm{C}$ content of the chromosomal DNA was analysed as described by Mesbah et al. (1989) using reversedphase HPLC. The DNA G+C content of strain Su $4^{\mathrm{T}}$ was $64.5 \mathrm{~mol} \%$. Strain $\mathrm{Su} 4^{\mathrm{T}}$ differed from members of the genera Thiohalomonas, Thiohalospira, Thiorhodospira, Alkalilimnicola and Alkalispirillum in its DNA G + C content (Table 1).

The present data demonstrated that the novel, chemolithoautotrophic, sulphur-oxidizing bacterium showed many unique features compared to members of related genera and its phylogenetic position was consistent in all the phylogenetic trees generated by using NJ and ML algorithms. The topology of the maximum-parsimony tree was clearly the same (data not shown). From the phylogenetic analyses, strain $\mathrm{Su} 4^{\mathrm{T}}$ could not be associated with any known genera and, therefore, appeared to constitute a new genus in the class Gammaproteobacteria. Strain $\mathrm{Su} 4^{\mathrm{T}}$ could also be differentiated physiologically from members of related genera, as shown in Table 1. Members of the reference genera were phototrophic, halophilic and/or alkaliphilic, whereas strain $\mathrm{Su} 4^{\mathrm{T}}$ was non-alkaliphilic (neutrophilic), non-phototrophic and only slightly halophilic, differentiating it from members of closely related genera in the class Gammaproteobacteria. Considering its low 16S rRNA gene sequence similarity $(<92 \%)$ to members of closely related taxa, its unique branching position in phylogenetic analyses and its physiological characteristics, it is clear that the isolate cannot be assigned to any previously recognized bacterial genus. Therefore, strain Su $4^{\mathrm{T}}$ represents a novel species of a novel genus, for which the name Thioalbus denitrificans gen. nov., sp. nov. is proposed.

\section{Description of Thioalbus gen. nov.}

Thioalbus [Thi.o.al'bus. Gr. n. theion (Latin transliteration thium) sulfur; L. masc. adj. albus white; N.L. masc. n. Thioalbus intended to mean a bacterium which oxidizes thiosulfate and whose colonies are white].

Cells are non-motile, Gram-reaction-negative rods. Obligately chemolithoautotrophic and facultatively anaerobic. Utilizes reduced sulfur compounds as electron donors with oxygen or nitrate as electron acceptors. Slightly halophilic and neutrophilic. Major cellular fatty acids are $\mathrm{C}_{16: 0}, \mathrm{C}_{16: 1} \omega 7 \mathrm{c} /$ iso- $\mathrm{C}_{15: 0}$ 2- $\mathrm{OH}$ and $\mathrm{C}_{18: 1} \omega 7 c / \omega 9 t / \omega 12 t$. Cells were isolated from marine sediment. The type species is Thioalbus denitrificans, a member of the Gammaproteobacteria.

\section{Description of Thioalbus denitrificans sp. nov.}

Thioalbus denitrificans (de.ni.tri.fi'cans. N.L. part. adj. denitrificans from N.L. v. denitrifico, denitrifying). 
Table 1. Characteristics of strain $\mathrm{Su} 4^{\top}$ and related genera

Taxa: 1, strain Su4 ${ }^{\mathrm{T}}$ (data from this study); 2, Thiohalomonas (Sorokin et al., 2007a); 3, Ectothiorhodospira (Imhoff, 2005; Ventura et al., 2000); 4, Thiohalospira (Sorokin et al., 2008); 5, Thiorhodospira (Bryantseva et al., 1999); 6, Thioalkalivibrio (Sorokin et al., 2002a; Sorokin et al., 2002c; Sorokin et al., 2001b); 7, Alkalilimnicola (Hoeft et al., 2007; Sorokin et al., 2006a; Yakimov et al., 2001); 8, Alkalispirillum (Rijkenberg et al., 2001; Sorokin et al., 2006a). +, Positive; -, negative; v, variable; ND, no data available; R, rod; LR, long rod; SR, short rod; VB, vibrioid; SP, spirilla; CLH, chemolithoheterotrophic; CLA, chemolithoautotrophic; PAL, photoautolithotrophic; POH, photo-organoheterotrophic.

\begin{tabular}{|c|c|c|c|c|c|c|c|c|}
\hline Characteristic & 1 & 2 & 3 & 4 & 5 & 6 & 7 & 8 \\
\hline Morphology & $\mathrm{R}$ & LR, VB & VB & SP & $\mathrm{VB}, \mathrm{SP}$ & SP & SR, LR & VB \\
\hline Pigment & - & $\mathrm{ND}$ & Red & Yellow & Red & Yellow, brown & - & - \\
\hline $\mathrm{pH}$ optimum & $7.0-7.5$ & $7.3-8.2$ & $7.6-10$ & $7.3-8.5$ & $9.0-9.5$ & $9.0-10$ & $9.3-9.5$ & $9.0-10$ \\
\hline $\mathrm{NaCl}$ range (\%) & $1-5$ & $5-20$ & $0-20$ & $3-29$ & $0-6$ & $2-23$ & $0-28$ & $0-25$ \\
\hline $\mathrm{NaCl}$ optimum (\%) & 3 & $5-12$ & $1-7$ & $11-20$ & $0.5-1$ & $5-12$ & $3-8$ & 2 \\
\hline Anaerobic growth & + & + & + & $\mathrm{v}$ & + & $\mathrm{v}$ & + & + \\
\hline Metabolism & CLA & CLA & PAL, POH, CLA & CLA & PAL & CLA & CLH, CLA & CLH, CLA \\
\hline DNA G $+C$ content $(\mathrm{mol} \%)$ & 64.5 & $58-60$ & $61-68$ & $65.6-67$ & $56-57$ & $61-66$ & $66-68$ & 66.2 \\
\hline
\end{tabular}

Table 2. Fatty acid compositions of strain $\mathrm{Su} 4^{\top}$ and related type species

Taxa: 1, strain Su $4^{\mathrm{T}} ; 2$, Thiohalomonas denitrificans HLD $2^{\mathrm{T}}$ (Sorokin et al., 2007a); 3. Ectothiorhodospira mobilis DSM $237^{\mathrm{T}}$ (Thiemann \& Imhoff, 1996). Values shown are percentages of total fatty acids. tr, Trace $(<1 \%)$; - , not detected; ECL, equivalent chain length.

\begin{tabular}{|lccc|}
\hline Fatty acid & $\mathbf{1}$ & $\mathbf{2}$ & $\mathbf{3}$ \\
\hline $\mathrm{C}_{10: 0} 3-\mathrm{OH}$ & 2.76 & $\operatorname{tr}$ & - \\
$\mathrm{C}_{12: 0} 3-\mathrm{OH}$ & 2.53 & 3.90 & - \\
$\mathrm{C}_{12: 0}$ - & 2.11 & - & - \\
$\mathrm{C}_{14: 0}$ & - & - & 1.20 \\
anteiso-C $15: 0$ & 2.32 & - & - \\
$\mathrm{C}_{16: 0}$ & 32.98 & 25.41 & 35.70 \\
$\mathrm{C}_{16: 0} 10-$-methyl & 4.40 & 1.26 & - \\
$\mathrm{C}_{16: 1} \omega 9 c$ & - & - & 2.70 \\
$\mathrm{C}_{16: 1} \omega 7 c$ & - & 27.27 & - \\
$\mathrm{C}_{16: 1} \omega 5 c$ & - & 2.97 & - \\
$\mathrm{C}_{17: 0}$ cyclo & - & 8.38 & - \\
$\mathrm{C}_{17: 1} 11-$-methyl & - & 2.53 & - \\
$\mathrm{C}_{18: 0}$ & 1.71 & $\operatorname{tr}$ & 7.60 \\
$\mathrm{C}_{18: 1} \omega 9 c$ & 2.43 & 5.10 & - \\
$\mathrm{C}_{18: 1} \omega 7 c$ & - & 11.84 & - \\
$\mathrm{C}_{18: 1} \omega 5 c$ & - & 1.64 & - \\
$\mathrm{C}_{18: 1} 11-$-methyl & - & 1.29 & - \\
$\mathrm{C}_{19: 0} \Delta 8,9$ & - & - & 33.80 \\
$\mathrm{C}_{19: 0}$ cyclo & - & 3.26 & - \\
Summed features & & & \\
4 & 32.47 & - & - \\
7 & 14.19 & - & 16.50 \\
Unknown $^{*}$ & 2.11 & - & - \\
& & & \\
\hline
\end{tabular}

* Summed features represent groups of two or three fatty acids that cannot be separated by a GC with the MIDI system. Summed feature 4 comprises $\mathrm{C}_{16: 1} \omega 7 c$ and/or iso- $\mathrm{C}_{15: 0} 2-\mathrm{OH}$, summed feature 7 comprises $\mathrm{C}_{18: 1} \omega 7 c / \omega 9 t / \omega 12 t$.
Cells are Gram-reaction-negative, oxidase- and catalasepositive, aerobic, denitrifying, rod-shaped $(0.5-0.8 \times 1.2-$ $1.5 \mu \mathrm{m})$ and have no flagellum. Cells are able to oxidize thiosulfate, tetrathionate, sulfide and elemental sulfur but not sulfite under the denitrifying conditions. Favourable growth occurs aerobically, forming circular colonies of $\sim 0.7-1.5 \mathrm{~mm}$ diameter with regular edges within 10 days of incubation at $10-40{ }^{\circ} \mathrm{C}$ (optimum $28-32{ }^{\circ} \mathrm{C}$ ). Elemental sulfur is accumulated via thiosulfate oxidation when cells are grown under anaerobic conditions (Supplementary Fig. S1). Does not use yeast extract, Tryptone, peptone, Casamino acids, succinate, glucose, glycerol, ethanol, methanol, pyruvate, malate, citrate, propionate, formate, proline, alanine, aspartic acid or serine as organic carbon sources or electron donors. Growth factors, such as vitamins, are not required. Neutrophilic, non-phototrophic and slightly halophilic. $\mathrm{NaCl}$ is required for growth. Optimum growth occurs at $\mathrm{pH} 7.0-7.5$ and in $3 \%(\mathrm{w} / \mathrm{v})$ $\mathrm{NaCl}$. Major cellular fatty acids are $\mathrm{C}_{16: 0}, \mathrm{C}_{16: 1} \omega 7 c /$ iso$\mathrm{C}_{15: 0} 2-\mathrm{OH}$ and $\mathrm{C}_{18: 1} \omega 7 c / \omega 9 t / \omega 12 t$.

The type strain, $\mathrm{Su} 4^{\mathrm{T}}$ (=KCTC $5699^{\mathrm{T}}=\mathrm{JCM} 15568^{\mathrm{T}}$ ), was isolated from a sulfur-oxidizing enrichment culture from marine sediment of the East Sea, South Korea. The DNA $\mathrm{G}+\mathrm{C}$ content of the type strain is $64.5 \mathrm{~mol} \%$ (as determined by HPLC).

\section{Acknowledgements}

This work was supported by the National Research Foundation of Korea (NRF) (grant no. 2009-0087901) funded by the Korea government (MEST) and the Marine and Extreme Genome Research Center Program of the Ministry of Land, Transportation and Maritime Affairs, Republic of Korea. We are grateful for the comments and suggestions of the editor and anonymous reviewers. We thank Dr J.P. Euzéby for doing background research when naming strain $\mathrm{Su} 4^{\mathrm{T}}$. 


\section{References}

Bryantseva, I., Gorlenko, V. M., Kompantseva, E. I., Imhoff, J. F., Süling, J. \& Mityushina, L. (1999). Thiorhodospira sibirica gen. nov., sp. nov., a new alkaliphilic purple sulfur bacterium from a Siberian soda lake. Int J Syst Bacteriol 49, 697-703.

Choi, B.-R., Pham, V. H., Park, S.-J., Kim, S.-J., Roh, D.-H. \& Rhee, S.-K. (2009). Characterization of facultative sulfur-oxidizing Marinobacter sp. BR13 isolated from marine sediment of Yellow Sea, Korea. J Korean Soc Appl Biol Chem 52, 309-314.

Chun, J., Lee, J. H., Jung, Y., Kim, M., Kim, S., Kim, B. K. \& Lim, Y. W. (2007). EzTaxon: a web-based tool for the identification of prokaryotes based on $16 \mathrm{~S}$ ribosomal RNA gene sequences. Int J Syst Evol Microbiol 57, 2259-2261.

Cline, J. D. (1969). Spectrophotometric determination of hydrogen sulfide in natural waters. Limnol Oceanogr 14, 454-458.

Dahl, C. \& Friedrich, C. G. (2007). Microbial Sulfur Metabolism. Berlin, Heidelberg: Springer.

Felsenstein, J. (1981). Evolutionary trees from DNA sequences: a maximum likelihood approach. J Mol Evol 17, 368-376.

Felsenstein, J. (1993). PHYLIP (phylogeny inference package), version 3.5. Distributed by the author. Department of Genome Sciences, University of Washington, Seattle, USA.

Friedrich, C. G., Rother, D., Bardischewsky, F., Quentmeier, A. \& Fischer, J. (2001). Oxidation of reduced inorganic sulfur compounds by bacteria: emergence of a common mechanism? Appl Environ Microbiol 67, 2873-2882.

Friedrich, C. G., Bardischewsky, F., Rother, D., Quentmeier, A. \& Fischer, J. (2005). Prokaryotic sulfur oxidation. Curr Opin Microbiol 8, 253-259.

Hall, T. A. (1999). BioEdit: a user-friendly biological sequence alignment editor and analysis program for Windows 95/98/NT. Nucleic Acids Symp Ser 41, 95-98.

Hoeft, S. E., Blum, J. S., Stolz, J. F., Tabita, F. R., Witte, B., King, G. M., Santini, J. M. \& Oremland, R. S. (2007). Alkalilimnicola ehrlichii sp. nov., a novel, arsenite-oxidizing haloalkaliphilic gammaproteobacterium capable of chemoautotrophic or heterotrophic growth with nitrate or oxygen as the electron acceptor. Int J Syst Evol Microbiol 57, 504-512.

Imhoff, J. F. (2005). The Proteobacteria. In Bergey's Manual of Systematic Bacteriology, pp. 43-48. Edited by D. J. Brenner, N. R. Krieg, J. T. Staley \& G. M. Garrity. New York: Springer.

Ito, T., Sugita, K. \& Okabe, S. (2004). Isolation, characterization, and in situ detection of a novel chemolithoautotrophic sulfur-oxidizing bacterium in wastewater biofilms growing under microaerophilic conditions. Appl Environ Microbiol 70, 3122-3129.

Kelly, D. P., McDonald, I. R. \& Wood, A. P. (2000). Proposal for the reclassification of Thiobacillus novellus as Starkeya novella gen. nov., comb. nov., in the alpha-subclass of the Proteobacteria. Int J Syst Evol Microbiol 50, 1797-1802.

Kimura, M. (1983). The Neutral Theory of Molecular Evolution. Cambridge: Cambridge University Press.

King, G. M. (2007). Chemolithotrophic bacteria: distributions, functions and significance in volcanic environments. Microbes Environ 22, 309-319.

Kletzin, A., Urich, T., Müller, F., Bandeiras, T. M. \& Gomes, C. M. (2004). Dissimilatory oxidation and reduction of elemental sulfur in thermophilic archaea. J Bioenerg Biomembr 36, 77-91.

Kolmert, A., Wikström, P. \& Hallberg, K. B. (2000). A fast and simple turbidimetric method for the determination of sulfate in sulfatereducing bacterial cultures. J Microbiol Methods 41, 179-184.
Kuenen, J. G. \& Robertson, L. A. (1992). The use of natural bacterial populations for the treatment of sulphur-containing wastewater. Biodegradation 3, 239-254.

McHatton, S. C., Barry, J. P., Jannasch, H. W. \& Nelson, D. C. (1996). High nitrate concentrations in vacuolate, autotrophic marine Beggiatoa spp. Appl Environ Microbiol 62, 954-958.

Mesbah, M., Premachandran, U. \& Whitman, W. B. (1989). Precise measurement of the $\mathrm{G}+\mathrm{C}$ content of deoxyribonucleic acid by highperformance liquid chromatography. Int J Syst Bacteriol 39, 159-167.

MIDI (1999). Sherlock Microbial Identification System, Operating Manual version 3.0. Newark, DE: MIDI.

Nakagawa, S. \& Takai, K. (2008). Deep-sea vent chemoautotrophs: diversity, biochemistry and ecological significance. FEMS Microbiol Ecol 65, 1-14.

Otte, S., Kuenen, J. G., Nielsen, L. P., Paerl, H. W., Zopfi, J., Schulz, H. N., Teske, A., Strotmann, B., Gallardo, V. A. \& Jorgensen, B. B. (1999). Nitrogen, carbon, and sulfur metabolism in natural Thioploca samples. Appl Environ Microbiol 65, 3148-3157.

Park, S. J., Kang, C. H. \& Rhee, S. K. (2006). Characterization of the microbial diversity in a Korean solar saltern by $16 \mathrm{~S}$ rRNA gene analysis. J Microbiol Biotechnol 16, 1640-1645.

Rijkenberg, M. J., Kort, R. \& Hellingwerf, K. J. (2001). Alkalispirillum mobile gen. nov., spec. nov., an alkaliphilic non-phototrophic member of the Ectothiorhodospiraceae. Arch Microbiol 175, 369-375.

Saitou, N. \& Nei, M. (1987). The neighbor-joining method: a new method for reconstructing phylogenetic trees. Mol Biol Evol 4, 406425.

Sorokin, D. Y. (2003). Oxidation of inorganic sulfur compounds by obligately organotrophic bacteria. Microbiology 72, 641-653.

Sorokin, D. Y. \& Mityushina, L. L. (1998). [Ultrastructure of alkaliphilic heterotrophic bacteria oxidizing sulfur compounds to tetrathionate]. Microbiology (English translation of Mikrobiologiya) 67, 78-85 (published in Russian with English translation).

Sorokin, D. Y., Lysenko, A. M. \& Mityushina, L. L. (1996). [Isolation and characterization of alkaliphilic chemoorganoheterotrophic bacteria oxidizing reduced inorganic sulfur compounds to tetrathionate.] Microbiology (English translation of Mikrobiologiya) 65, 326-338 (published in Russian with English translation).

Sorokin, D. Y., Robertson, L. A. \& Kuenen, J. G. (2000). Isolation and characterization of alkaliphilic, chemolithoautotrophic, sulphuroxidizing bacteria. Antonie van Leeuwenhoek 77, 251-262.

Sorokin, D. Y., Kuenen, J. G. \& Jetten, M. S. M. (2001a). Denitrification at extremely high $\mathrm{pH}$ values by the alkaliphilic, obligately chemolithoautotrophic, sulfur-oxidizing bacterium Thioalkalivibrio denitrificans strain ALJD. Arch Microbiol 175, 94-101.

Sorokin, D. Y., Lysenko, A. M., Mityushina, L. L., Tourova, T. P., Jones, B. E., Rainey, F. A., Robertson, L. A. \& Kuenen, G. J. (2001b). Thioalkalimicrobium aerophilum gen. nov., sp. nov. and Thioalkalimicrobium sibericum sp. nov., and Thioalkalivibrio versutus gen. nov., sp. nov., Thioalkalivibrio nitratis sp.nov., and Thioalkalivibrio denitrificancs sp. nov., novel obligately alkaliphilic and obligately chemolithoautotrophic sulfur-oxidizing bacteria from soda lakes. Int $J$ Syst Evol Microbiol 51, 565-580.

Sorokin, D. Y., Tourova, T. P., Lysenko, A. M., Mityushina, L. L. \& Kuenen, J. G. (2002a). Thioalkalivibrio thiocyanoxidans sp. nov. and Thioalkalivibrio paradoxus sp. nov., novel alkaliphilic, obligately autotrophic, sulfur-oxidizing bacteria capable of growth on thiocyanate, from soda lakes. Int J Syst Evol Microbiol 52, 657-664.

Sorokin, D. Y., Tourova, T. P., Kolganova, T. V., Sjollema, K. A. \& Kuenen, J. G. (2002b). Thioalkalispira microaerophila gen. nov., sp. nov., a novel lithoautotrophic, sulfur-oxidizing bacterium from a soda lake. Int J Syst Evol Microbiol 52, 2175-2182. 
Sorokin, D. Y., Gorlenko, V. M., Tourova, T. P., Tsapin, A. I., Nealson, K. H. \& Kuenen, G. J. (2002c). Thioalkalimicrobium cyclicum sp. nov. and Thioalkalivibrio jannaschii sp. nov., novel species of haloalkaliphilic, obligately chemolithoautotrophic sulfur-oxidizing bacteria from hypersaline alkaline Mono Lake (California). Int J Syst Evol Microbiol 52, 913-920.

Sorokin, D. Y., Zhilina, T. N., Lysenko, A. M., Tourova, T. P. \& Spiridonova, E. M. (2006a). Metabolic versatility of haloalkaliphilic bacteria from soda lakes belonging to the AlkalispirillumAlkalilimnicola group. Extremophiles 10, 213-220.

Sorokin, D. Y., Tourova, T. P., Kolganova, T. V., Spiridonova, E. M., Berg, I. A. \& Muyzer, G. (2006b). Thiomicrospira halophila sp. nov., a moderately halophilic, obligately chemolithoautotrophic, sulfuroxidizing bacterium from hypersaline lakes. Int J Syst Evol Microbiol 56, 2375-2380.

Sorokin, D. Y., Tourova, T. P., Braker, G. \& Muyzer, G. (2007a). Thiohalomonas denitrificans gen. nov., sp. nov. and Thiohalomonas nitratireducens sp. nov., novel obligately chemolithoautotrophic, moderately halophilic, thiodenitrifying gammaproteobacteria from hypersaline habitats. Int J Syst Evol Microbiol 57, 1582-1589.

Sorokin, D. Y., Tourova, T. P., Bezsoudnova, E. Y., Pol, A. \& Muyzer, G. (2007b). Denitrification in a binary culture and thiocyanate metabolism in Thiohalophilus thiocyanoxidans gen. nov. sp. nov. - a moderately halophilic chemolithoautotrophic sulfur-oxidizing gammaproteobacterium from hypersaline lakes. Arch Microbiol 187, 441-450.

Sorokin, D. Y., Tourova, T. P., Muyzer, G. \& Kuenen, G. J. (2008). Thiohalospira halophila gen. nov., sp. nov. and Thiohalospira alkaliphila sp. nov., novel obligately chemolithoautotrophic, halophilic, sulfur-oxidizing gammaproteobacteria from hypersaline habitats. Int J Syst Evol Microbiol 58, 1685-1692.

Strickland, J. D. H. \& Parsons, T. R. (1968). A Manual for Sea Water Analysis. Bull. Fish. Res. Bd. Canada, 167.

Tamura, K., Dudley, J., Nei, M. \& Kumar, S. (2007). MEGA4: molecular evolutionary genetics analysis (MEGA) software version 4.0. Mol Biol Evol 24, 1596-1599.
Thiemann, B. \& Imhoff, J. F. (1996). Differentiation of Ectothiorhodospiraceae based on their fatty acid composition. Syst Appl Microbiol 19, 223-230.

Thompson, J. D., Gibson, T. J., Plewniak, F., Jeanmougin, F. \& Higgins, D. G. (1997). The CLUSTAL_X windows interface: flexible strategies for multiple sequence alignment aided by quality analysis tools. Nucleic Acids Res 25, 4876-4882.

Ventura, S., Viti, C., Pastorelli, R. \& Giovannetti, L. (2000). Revision of species delineation in the genus Ectothiorhodospira. Int J Syst Evol Microbiol 50, 583-591.

Voroteliak, V., Cowley, D. M. \& Florin, T. H. (1993). Improved colorimetric determination of urinary thiosulfate to study intermediate sulfur metabolism in humans. Clin Chem 39, 25332534.

Wayne, L. G., Brenner, D. J., Colwell, R. R., Grimont, P. A. D., Kandler, O., Krichevsky, M. I., Moore, L. H., Moore, W. E. C., Murray, R. G. E. \& other authors (1987). Report of the ad hoc committee on reconciliation of approaches to bacterial systematics. Int J Syst Bacteriol 37, 463464.

Weisburg, W. G., Barns, S. M., Pelletier, D. A. \& Lane, D. J. (1991). 16S ribosomal DNA amplification for phylogenetic study. J Bacteriol 173, 697-703.

Widdel, F. \& Bak, F. (1992). Gram-negative mesophilic sulfatereducing bacteria. In The prokaryotes, 2nd edn, pp. 3352-3378. Edited by A. Balows, H. G. Trüper, M. Dworkin, W. Harder \& K.-H. Schleifer. Berlin, Germany: Springer.

Wolin, E. A., Wolin, M. J. \& Wolfe, R. S. (1963). Formation of methane by bacterial extracts. J Biol Chem 238, 2882-2886.

Yakimov, M. M., Giuliano, L., Chernikova, T. N., Gentile, G., Abraham, W. R., Lünsdorf, H., Timmis, K. N. \& Golyshin, P. N. (2001). Alcalilimnicola halodurans gen. nov., sp. nov., an alkaliphilic, moderately halophilic and extremely halotolerant bacterium, isolated from sediments of soda-depositing Lake Natron, East Africa Rift Valley. Int J Syst Evol Microbiol 51, 2133-2143. 